\title{
Organik Materyal Kullanımının Alkali Bir Toprağın Bazı Islah Göstergeleri Üzerine Etkisi
}

\author{
Barıș GÖKOĞLU' \\ Gökhan $\mathrm{CAYCl}^{2}$ \\ 'Meteoroloji Genel Müdürlüğü, Meteoroloji 1. Bölge Müdürlüğü, İstanbul \\ ${ }^{2}$ Ankara Üniversitesi, Ziraat Fakültesi, Toprak Bilimi ve Bitki Besleme Bölümü, Ankara
}

\begin{abstract}
*Sorumlu yazar e-mail (Corresponding author e-mail): peacegok@yahoo.com
Geliș tarihi (Received) : 20.08.2020

Kabul tarihi (Accepted): 06.02.2021

DOI: $10.21657 /$ topraksu.782950
\end{abstract}

\section{Öz}

Alkali topraklar içerdikleri yüksek miktarda değișebilir sodyum ve yüksek pH değerleri ile bitki yetiștirilmesi bakımından verimsizdirler ve kötü fiziksel, kimyasal ve biyolojik özellikler sergilerler. Buna rağmen uygun teșhis ve ıslah yöntemleriyle tarıma kazandırımaları mümkündür. Bu çalıșmada, çiftlik gübresi (ÇG), bira fabrikası atığı (BFA), tavuk gübresi (TG) ve jipsin birlikte uygulamalarının alkali toprak ıslahındaki etkinliği araștırılmıștır. Araștırma tesadüf parselleri deneme deseninde 3 tekerrürlü olarak 33 adet PVC kolonda yürütülmüștür. Alkali toprağa, jips ve organik materyaller 1. \% 100 Jips gereksinimi (JG) 2. \%50 JG 3. $\% 50 \mathrm{JG}+\% 1$ CG 4. \%50 JG + \%2 ÇG 5. \%50 JG + \%4 CG 6. \%50 JG + \%1 BFA 7. \%50 JG + \%2 BFA 8. $\% 50 \mathrm{JG}+\% 4$ BFA 9. \%50 JG + \%1 TG 10. \%50 JG + \%2 TG 11.\%50 JG + \%4 TG deneme planına göre uygulanmıștır. Elde edilen sonuçlar, alkali toprağa jips ve organik materyal uygulamalarının ıslah parametreleri olarak kabul edilen pH, EC, ESP ve SAR değerlerinde önemli değișimlere neden olduğunu göstermiștir. Çiftlik gübresinin ESP değerini düșürmede diğer organik materyallere nazaran kısmen daha etkili olduğu görülmüștür. Organik materyallerin uygulama düzeyleri dikkate alındığında ise ÇG, BFA ve TG'nin \%4 dozlarının diğer dozlardan daha etkili olduğu saptanmıștır.

Anahtar Kelimeler: Toprak ıslahı, jips, çiftlik gübresi, tavuk gübresi, bira fabrikası atığı

\section{Effect of Organic Material Usage on Some Reclamation Parameters of an Alkali Soil}

\begin{abstract}
Alkali soils are infertile for plant growing because of containing high amounts of exchangeable sodium and high $\mathrm{pH}$ values and exhibit poor physical, chemical and biological properties. However, it is possible to improve them with appropriate diagnosis and reclamation methods. In this study, the efficiency of the combined application of farmyard manure (FYM), beer factory sludge (BFS), chicken manure (CM) and gypsum in alkali soil reclamation was investigated. The study was conducted in randomized complete parcels with three replications in 33 PVC colons. Gypsum and organic materials were added as follows:1. 100 gypsum requirement ; (GR), 2. $50 \%$ GR,3. $50 \%$ GR + $1 \%$ FYM, $4.50 \%$ GR + $2 \%$ FYM 5. $50 \%$ GR + $4 \%$ FYM, 6. $50 \%$ GR + 1\% BFS, 7. $50 \%$ GR + $2 \%$ BFS, $8.50 \%$ GR +4 $\%$ BFS 9. $50 \%$ GR $+1 \%$ CM, 10.50 \% GR + $2 \%$ CM, 11.50\% GR + $4 \%$ CM. The results revealed that the application of gypsum and organic materials to alkali soil caused significant changes in $\mathrm{pH}, \mathrm{EC}, \mathrm{ESP}$, and SAR values considered as reclamation parameters. Farmyard manure was partially more effective than other organic materials in reducing ESP. As application levels of the organic materials considered, $4 \%$ doses of BFS, FYM and CM were more effective than other doses to decrease alkalinity.
\end{abstract}

Keywords: Soil reclamation, gypsum, farmyard manure, chicken manure, beer factory sludge 


\section{Gíriș}

Toprak tuzluluğu çeșitli tuzların bitki gelișimini engelleyecek düzeyde toprakta birikmesidir. Topraktaki tuzluluğun artması çoraklașmayı ve beraberinde çölleșmeyi arttırmakta ve aynı zamanda çok önemli bir çevre sorunu olarak karșımıza çıkmaktadır.

Dünyanın her kıtasında, özellikle kurak ve yarı kurak iklim bölgelerinde yaygın olarak bulunan tuzdan etkilenmiș topraklar, kültür bitkilerinin gelișmesini engelleyecek düzeyde çözünebilir tuzlar ve/veya değișebilir sodyum ya da her ikisini birden içerir ve özel bir toprak yönetimi gerektirirler (Bahtiyar, 1971).Yapılan birçok çalıșma tuzdan etkilenmiș toprakların olușumunda; iklim, drenaj, ana materyal, topografik yapı, toprak ve su yönetim uygulamalarının etkili olduğunu ortaya koymaktadır.

Türkiye Geliștirilmiș Toprak Haritası etütlerinde kullanılan tuzluluk ve alkalilik kriterlerine göre ülkemizde 1518722 ha alanda tuzluluk ve alkalilik (çoraklık) sorunu bulunmaktadır. Bu miktarın \%41'i hafif tuzlu, \%33'ü tuzlu, \%0.5'i alkali, \%8'i hafif tuzlu alkali ve \%17.5'i tuzlu alkalidir. Corak araziler ülkemiz yüzölçümünün \%2'sine, toplam ișlenen tarım arazilerinin \%5.48'ine eșdeğer büyüklüktedir. Mülga Köy Hizmetleri Genel Müdürlüğünün il arazi varlığı raporları dikkate alınarak 2000'li yıllarda yapılan değerlendirmelerinde arazilerin kullanma șekilleri itibariyle Türkiye'de kuru tarım alanlarının 163638 hektarında, sulu tarım alanlarının 449709 hektarında, bağ-bahçe alanlarının 9050 hektarında, çayır-mera kullanım alanlarının 733 422 hektarında, orman-funda alanlarının 11436 hektarında çoraklık sorunu bulunmaktadır (Sönmez ve Beyazgül, 2008).

Tuzdan etkilenmiș topraklar arasında yer alan alkali topraklarda, fazla miktardaki değișebilir sodyum ve yüksek $\mathrm{pH}$ değerleri, toprak strüktürünün bozulmasına ve kilin dispersiyonuna neden olmakta ve buna bağlı olarak toprakların hava ve su geçirgenliği sınırlanmaktadır. Sodyumca zengin alkali toprakların içerdiği yüksek sodyumun zararlarını azaltmanın en pratik yolu sodyumun yerine geçebilecek kalsiyum katyonunun değișim ortamına ilavesidir. Alkali toprakların ıslahında birçok yöntem toprakların özel durumuna göre kullanılmıștır. Bu yöntemler içerisinde kimyasal ıslah maddesi kullanımı en yaygın kullanılan yöntemdir.
Diğer taraftan masraflı bir ișlem olan alkali toprak ıslahında masrafları azaltma, özellikle de kimyasal ıslah maddesi masraflarını azaltmak için çabalar harcanmıștır (Qadir vd., 2001). Tozsin vd. (2014) kireçli ve alkali toprağın ıslahında jipse alternatif olarak kullandıkları pirit atıklarının toprakta herhangi bir ağır metal kirliliğine neden olmadan ıslahta kullanılabileceğini göstermișlerdir.

Organik materyaller sahip oldukları fiziksel ve kimyasal özellikleri sayesinde doğada dinamik bir döngü yașanmasına, toprak ekosisteminin sürekli olarak yenilenmesine ve toprak kalitesinin arttırılmasına olanak sağlamaktadırlar. Günümüzde organik madde toprak kalitesinin ve sürdürülebilir toprak yönetiminin vazgeçilmez bir unsuru olarak değerlendirilmektedir. Alkali toprak ıslahında kullanılan organik materyallerin değișik tipleri toprak strüktürüne farklı etkiler yapmakla beraber, onların genel etkisi taneleri bir araya getirme șeklinde olmaktadır (Nelson ve Oades, 1998).

Puttaswamygowda ve Pratt (1973) organik materyallerin parçalanmasına bağlı olarak açığa çıkan organik asitlerin ve CO2'nin, pH'ın düșmesi, kireç ve diğer toprak minerallerinin çözünürlüğüne bağlı olarak katyonların açığa çıkması ve değișebilir sodyumun, kalsiyum ve magnezyumla değișimiyle birlikte, değișebilir sodyum yüzdesinin azalarak alkali toprak ıslahına katkıda bulunduğunu belirtmișlerdir. Diğer taraftan Bose vd. (1992), alkali (ESP= 19.8) toprağın ıslahında çiftlik gübresinin etkili olduğunu belirtirken, ıslah etkinliğinin derinlikle azalmıș olduğunu vurgulamıșlardır. Hanay vd. (2004), belediye katı atık kompostu ve ardıșı jips uygulamalarının tuzlu-alkali toprağın ıslah edilmesinde etkili olduklarını ve sorunlu toprağın tekrar geri kazandırılabileceğini bildirmișlerdir. Tejada vd. (2006), pamuk çırçır atığı ve tavuk gübresi ilavelerinin alkaliliğin azaltılmasında önemli derecede katkılar sağladığını bildirmișlerdir. Ghosh vd. (2010) ise, Avusturalya toprak sınıflamasına göre orta alkali (ESP 6-15) ve kuvvetli alkali (ESP> 15) topraklara pamuk çırçır atığı, sığır gübresi ve tavuk gübresi gibi organik atıkların ilavesinin toprakların dispersiyon indislerini önemli derecede azalttığını bildirmișlerdir. Araștırıcılar bu etkinin orta alkali toprakta pamuk çırçır atığında, buna karșın kuvvetli alkali toprakta ise tavuk gübresinde diğer atıklardan daha belirgin olduğunu bildirmișlerdir. 
Topraktaki yüksek sodyum konsantrasyonunun, toprağın tekstürü, strüktürü, çözeltideki Ca ve Mg konsantrasyonu gibi birçok faktörle ilișkili olarak, toprağın infiltrasyon ve hidrolik iletkenlik değerlerini düșürdüğü, yüzey kabuğu olușumunu ve dispersiyonu teșvik ettiği belirtilmiștir. Ayrıca, sulama suyunun EC değerindeki artıșa paralel olarak toprakta agregat olușumunun teșvik edildiği ve yüzey akıș değerinin azaldığı bildirilmiștir (Yakupoğlu ve Özdemir, 2007).

Koc (2011), tuzlu-alkali (ECe $=4.54-9.67$ $\mathrm{dS} / \mathrm{m} ; \quad \mathrm{ESP}=49.1$ - 62.0) topraklarda yaptığı çalıșmada, jips dozları, yıkama suyu yöntemleri ve jips karıștırılma derinliğinin alkaliliği azaltmadaki etkilerini araștırmıștır. Yıkama suyu uygulama yöntemlerine bağı olarak jipsin toprağa uygulama derinliklerinin önemli değișimler gösterdiğini vurgulamıștır. Ranjbar ve Jalali (2011) ise, buğday, patates, ayçiçeği ve kolza artıklarının ve farklı düzeyde tuzluluk (SAR=10 ve $S A R=40$ ) içeren yıkama sularının alkali toprağın ıslahında etkinliğini inceledikleri çalıșmada, organik artıkların topraktaki sodyumun yıkanmasını arttırmak suretiyle ıslaha yardımcı olduklarını bildirmișlerdir. Yurtseven (2000), patlıcan yetiștirilen alanlarda, farklı tuzluluk ve $\mathrm{Ca} / \mathrm{Mg}$ oranlarındaki sulama sularının, toprak profil $(0-90 \mathrm{~cm})$ tuzluluğunun değișimine olan etkilerini incelemiștir. Araștırma sonucunda yüksek tuz konsantrasyonuna sahip sulama suyu ile sulanan toprak profilinde tuzluluğun özellikle 0-40 cm de yoğunlaștığını belirtmiștir.

Günümüzde toprağın organik madde düzeyini yükseltmek amacıyla topraklara ilave edilebilecek geleneksel organik madde kaynakları sınırlıdır. Diğer taraftan ülkemizde tarımsal ve endüstriyel ürünlerin ișlenmesi esnasında birçok organik atık ve artık açığa çıkmaktadır. Çoğu zaman bu atıklar ișletmelerin kullanım sahasında büyük alanlar ișgal ederek çalıșma düzenini bozmakta, depolama sorunları yaratmakta ve çevre sorunlarına neden olmaktadır (Kütük ve Çaycı, 2000). Tarımsal üretimde açığa çıkan atık materyallerin çevre kirliğine yol açmadan toprakların sürdürülebilir yönetimi amacıyla kullanılması gereklidir. Temiz vd, (2021) hayvansal ve bitkisel kökenli atıklardan elde ettikleri kompost materyallerinin agregat stabilitesi ve hidrolik iletkenlik bașta olmak üzere toprağın agregasyon özelliklerini önemli derecede arttırdığını bildirmișlerdir.

Bu çalıșmanın amacı, farklı özelliklere sahip çiftlik gübresi (ÇG), bira fabrikası atığı (BFA) ve tavuk gübresi (TG) gibi organik materyallerin, farklı dozlardaki jipsle birlikte uygulanmalarının alkali toprak ıslahındaki etkinliğinin incelenmesidir.

\section{MATERYAL VE YÖNTEM}

Araștırmada kullanılan toprak örneği Tarım ve Orman Bakanlığı, Toprak, Gübre ve Su Kaynakları Araștırma Enstitüsünün, Araștırma ve Uygulama istasyonu arazisinin 0-30 cm toprak katmanından alınmıștır. Araștırma ve Uygulama İstasyonu Ankara'ya 30 km uzaklıkta, Kahramankazan ilçesi sınırlarında olup Düger mevkiinde yer almaktadır. Doğusunda E-5 Karayolu, batısında TEM otoyolu, kuzeyinde ise Ankara Üniversitesi Veteriner Fakültesi arazileri ile sınır olușturmaktadır. Araștırma toprağının bazı fiziksel ve kimyasal özellikleri Çizelge 1'de verilmiștir. Denemede kimyasal saf jips kullanılmıștır. Organik ıslah materyali olarak kullanılan çiftlik gübresi Ankara Üniversitesi Ziraat Fakültesi hayvancılık ișletmesinden, bira fabrikası atığı Ankara'nın Kahramankazan ilçesindeki bira fabrikasından, tavuk gübresi ise özel bir tavukçuluk ișletmesinden sağlanmıștır.

Çizelge 1. Araștırma toprağının bazı fiziksel ve kimyasal özellikleri

Table 1. Some properties of soil used in study.

\begin{tabular}{lc}
\hline Kum, \% & 6.03 \\
Silt, \% & 35.50 \\
Kil, \% & 58.47 \\
Bünye & Kil \\
Organik Madde,\% & 1.93 \\
Bor, ppm & 9.02 \\
Kireç, \% & 6.2 \\
Hacim Ağılığı, g/cm ${ }^{3}$ & 1.2 \\
KDK, me/100 g & 52 \\
PH (Saturasyon Çamuru) & 9.0 \\
EC (Saturasyon Ekstraktı), dS/m & 3.9 \\
SAR & 61.0 \\
ESP & 50.0 \\
\hline
\end{tabular}

Araștırma sera koșullarında, 11 uygulama konulu ve 3 tekerrürlü olarak tesadüf parselleri deneme deseninde toplam 33 adet bozulmuș toprak örneklerinin yerleștirildiği kolonda yürütülmüștür. Denemede $25 \mathrm{~cm}$ boy ve $9 \mathrm{~cm}$ iç çapa sahip PVC kolonlar kullanılmıștır. PVC kolonlar birbirine geçmeli iki kısımdan olușmuștur. Kolonun alt kısmı 20 cm yükseklikte, üstüne geçen ve su yükü olușturulan üst kısmı $5 \mathrm{~cm}$ yüksekliktedir. PVC kolonların taban kısmına, ıslah sırasında yıkama suyunun kolayca drene olabilmesi için süzgeç konulmuștur. Ayrıca olası toprak kaybının 
önlenmesi için de süzgeç üzerine filtre görevi yapacak tülbent bez serilmiștir.

Deneme planı; 1. \%100 Jips gereksinimi (JG) 2. $\% 50 \mathrm{JG}$ 3. $\% 50 \mathrm{JG}+\% 1 \mathrm{CG} 4 . \% 50 \mathrm{JG}+\% 2$ CG 5. \%50 JG + \%4 CG 6. \%50 JG + \%1 BFA 7. $\% 50 \mathrm{JG}+\% 2$ BFA 8. $\% 50 \mathrm{JG}+\% 4$ BFA 9. $\% 50 \mathrm{JG}+\% 1 \mathrm{TG}, 10 . \% 50 \mathrm{JG}+\% 2 \mathrm{TG} 11$. \%50 JG + \%4 TG olarak yapılmıștır. Denemede kullanılan organik materyallerinin bazı özellikleri Çizelge 2'de verilmiștir. Her bir kolona ilave edilecek ÇG, BFA ve TG miktarları ağırlık temelinde 1600 gr kuru toprak üzerinden hesaplanmıștır. Topraklara karıștırılan organik materyallerin mineralizasyonunu artırmak için PVC kolonlar, sera koșullarında 60 gün boyunca, toprağın tarla kapasitesi nem düzeyinde inkübasyona tabi tutulmuștur. İnkübasyon periyodunun ardından, \% 100 JG kolonu için 24 gr jips, diğer kolonlar için ise 12 gr jips uygulanmıștır.

Çizelge 2. Denemede uygulanan organik materyallerin bazı özellikleri

Table 2. Some properties of organic materials used in study Organik Materyal $\mathrm{pH} \quad \mathrm{EC}, \mathrm{dS} / \mathrm{m}$ Organik madde \%

$\begin{array}{cccc}\text { CG } & 7.4 & 1.2 & 66.3 \\ \text { BFA } & 6.02 & 1.8 & 28.5 \\ \text { TG } & 7.0 & 2.9 & 76.6\end{array}$

ÇG: Çiftlik Gübresi; BFA: Bira fabrikası Atığı; TG: Tavuk Gübresi

Yıkama ișlemi 33 adet PVC kolonda uygulanmıștır. Yıkama çalıșmasında, aralıklı göllendirme yöntemi uygulanmıștır. Yıkama ișlemi esnasında elektriksel iletkenliği $102 \mu \mathrm{mhos} / \mathrm{cm}$ olan șehir șebeke suyu kullanılmıștır. Yıkama suyu ihtiyacı, 5' er cm' lik kısımlar halinde toplam $30 \mathrm{~cm}$ olacak șekilde uygulanmıștır. Yıkama suyu miktarının belirlenmesinde toprağın bünyesi de dikkate alınarak ıslah edilecek toprak derinliğinin 1,5 katı yıkama suyu uygulanmıștır (Abrol vd., 1988).

Hacim ağılığı parafin yöntemiyle I U.S. Salinity Lab. Staff, 1954), elektriksel iletkenlik değeri saturasyon ekstraktında (ECe) elektriksel iletkenlik aleti ile (U.S. Salinity Lab. Staff, 1954), tekstür, Bouyoucous (1951)' in geliștirmiș olduğu hidrometre yöntemi, toprak örneklerinin bünye sınıfları ise bünye üçgeninden yararlanılarak (Akalan, 1977), pH değerleri saturasyon çamurunda cam elektrotlu pH metre (U.S. Salinity Lab. Staff, 1954) ile belirlenmiștir.

Saturasyon ekstraktında Ca ve Mg EDTAile; $\mathrm{CO}_{3}$, $\mathrm{HCO}_{3} 0.01 \mathrm{~N} \mathrm{H}_{2} \mathrm{SO}_{4}$ ile; $\mathrm{Cl} 0.005$ N AgNO3'la titre etmek suretiyle; Na ve K flamefotometre; SO4 ise hesaplama yoluyla bulunmuștur (U.S. Salinity Lab. Staff, 1954). Katyon Değișim Kapasitesi, toprak örneklerinin sodyum asetat çözeltisi ile muamele edilerek flamefotometrede sodyum okuması yapılarak tayin edilmiștir ( Bower vd., 1952).

Organik madde modifiye edilmiș Walkley Black yöntemi ile tayin edilmiștir (U.S. Salinity Lab. Staff, 1954; Ülgen ve Ateșalp, 1972). Sodyum adsorbsiyon oranı $(\mathrm{SAR})=\mathrm{Na} /(\mathrm{Ca}+\mathrm{Mg})^{1 / 2}$ formülü kullanılarak belirlenmiștir (U.S. Salinity Lab. Staff, 1954). Değișebilir sodyum yüzdesi $(E S P)=1.475$ (SAR) / (1 + 0.0147 SAR) formülü kullanılarak bulunmuștur (U.S. Salinity Lab. Staff, 1954). Denemede kullanılan \% 100 jips gereksinimi bașlangıç ESP değerinin 15 değerine düșürülmesi esas alınarak hesaplanmıștır (Munsuz vd., 2001).

Organik materyallerin analizleri; Organik madde materyallerin $500 \pm 50^{\circ} \mathrm{C}^{\prime}$ de 4 saat süreyle yakılması ve organik madde kayıplarının fırın kuru ağırlık üzerinden hesaplanması esasına dayanan kuru yakma yöntemiyle bulunmuștur (DIN 11542, 1978).

Toprak reaksiyonu $(\mathrm{pH}), 1: 3$ oranında organik materyal-saf su karıșımında hidrojen iyon aktivitesinin $\mathrm{pH}$ - metre yardımıyla potansiyometrik olarak ölçülmesiyle (Gabriels ve Verdonck, 1992), elektriksel iletkenlik (EC), 1:3 oranında organik materyal - saf su karıșımından elde edilen süzükte elektriksel akıma karșı direncin ölçülmesiyle belirlenmiștir (Gabriels ve Verdonck, 1992). Sayısal verilerin değerlendirilmesinde Mstat ve Minitab paket programları kullanılmıștır.

\section{BULGULAR VE TARTIȘMA}

Islah parametreleri olarak kabul edilen $\mathrm{pH}, \mathrm{EC}$, ESP ve SAR değerlerinde uygulamalar sonucunda ortaya çıkan değișimler Çizelge 3'de sunulmuștur.

\section{Toprak Reaksiyonu (pH) Değerlerinin Değișimi}

Deneme toprağının bașlangıçta 9,0 olan $\mathrm{pH}^{\prime}$ sı ıslahtan sonra \%50 JG + \%4 BFA uygulamasında 8,25'e kadar düșmüștür. Aynı zamanda diğer organik materyal uygulamalarında da $\mathrm{pH}$ değerlerinde bașlangıç değerine göre düșüșler görülmüștür (Çizelge 3). \%100 jips gereksinimi ve \% 50 jips gereksinimi uygulamaları karșılaștırıldığında, \% 100jips gereksiniminin, \%50 jips gereksinimine göre $\mathrm{pH}$ değerini düșürmede çok da etkili olmadığı, iki uygulama arasındaki pH farklıığının istatistiksel olarak önemli olmadığı 
Çizelge 3. Uygulamalara bağlı olarak yıkama sonrası ıslah parametrelerindeki değișimler.

Table 3. Changes in reclamation parameters after leaching related to applications.

\begin{tabular}{lcccc}
\hline Uygulamalar & $\mathrm{PH}$ & $\mathrm{EC}, \mathrm{dS} / \mathrm{m}$ & $\mathrm{ESP}$ & SAR \\
\hline$\% 100 \mathrm{JG}$ & $8.43 \mathrm{AB}$ & $5.27 \mathrm{ABCD}$ & $27.25 \mathrm{D}$ & $25.28 \mathrm{D}$ \\
$\% 50 \mathrm{JG}$ & $8.50 \mathrm{ABCD}$ & $5.00 \mathrm{DEF}$ & $33.07 \mathrm{ABC}$ & $33.39 \mathrm{BC}$ \\
$\% 50 \mathrm{JG}+\% 1 \mathrm{CG}$ & $8.79 \mathrm{~A}$ & $5.03 \mathrm{CDEF}$ & $33.30 \mathrm{ABC}$ & $33.65 \mathrm{ABC}$ \\
$\% 50 \mathrm{JG}+\% 2 \mathrm{CG}$ & $8.60 \mathrm{ABC}$ & $4.97 \mathrm{EF}$ & $32.26 \mathrm{BC}$ & $32.10 \mathrm{C}$ \\
$\% 50 \mathrm{JG}+\% 4 \mathrm{CG}$ & $8.70 \mathrm{AB}$ & $4.77 \mathrm{~F}$ & $31.67 \mathrm{C}$ & $31.24 \mathrm{C}$ \\
$\% 50 \mathrm{JG}+\% 1 \mathrm{BFA}$ & $8.61 \mathrm{ABC}$ & $5.40 \mathrm{AB}$ & $34.06 \mathrm{AB}$ & $35.49 \mathrm{AB}$ \\
$\% 50 \mathrm{JG}+\% 2 \mathrm{BFA}$ & $8.30 \mathrm{CD}$ & $5.17 \mathrm{BCDE}$ & $32.95 \mathrm{ABC}$ & $33.15 \mathrm{BC}$ \\
$\% 50 \mathrm{JG}+\% 4 \mathrm{BFA}$ & $8.25 \mathrm{D}$ & $5.00 \mathrm{DEF}$ & $32.24 \mathrm{BC}$ & $32.08 \mathrm{C}$ \\
$\% 50 \mathrm{JG}+\% 1 \mathrm{TG}$ & $8.46 \mathrm{ABCD}$ & $5.43 \mathrm{AB}$ & $34.78 \mathrm{~A}$ & $35.93 \mathrm{AB}$ \\
$\% 50 \mathrm{JG}+\% 2 \mathrm{TG}$ & $8.39 \mathrm{BCD}$ & $5.50 \mathrm{~A}$ & $35.05 \mathrm{~A}$ & $36.46 \mathrm{~A}$ \\
\hline $50+\% 4 \mathrm{TG}$ & $8.69 \mathrm{AB}$ & $5.30 \mathrm{ABC}$ & $33.56 \mathrm{ABC}$ & $34.07 \mathrm{ABC}$ \\
\hline
\end{tabular}

Aynı harfle gösterilen değerler arasındaki fark önemli değildir.

PH LSD 0.05: 0.211, EC LSD 0.05: 0.197, ESP LSD 0.05: 1.390, SAR LSD 0.05: 1.902

görülmüștür. Çizelge 4'den görüleceği üzere, organik materyaller ve uygulama dozlarıyla ilișkili olarak pH için yapılan varyans analizinde (organik materyal $x$ doz) arasındaki interaksiyon önemli bulunmuștur $(P<0.05)$. Uygulanan üç organik materyalin $\mathrm{pH}$ üzerine etkisi BFA hariç dalgalı bir seyir göstermiștir. Organik materyal uygulamaları arasında \%2 BFA ve \%4 BFA uygulamalarının toprak $\mathrm{pH}^{\prime}$ nı düșürmede diğerlerine nazaran daha etkili oldukları saptanmıștır. Bununla beraber $\% 2$ BFA ve \% 4 BFA uygulamaları arasındaki fark istatistiksel olarak önemli bulunmamıștır. BFA' nın $\mathrm{pH}$ değerini düșürmede etkili olmasında, orijinal olarak pH değerinin diğer organik materyallerden daha düșük olması yanında, Baran vd. (1998)'in belirttiği üzere, yapısındaki organik asitlerin özellikle humik asitlerin fazla miktarda bulunması etkili olabilir. Organik materyallerin yapısında bulunan humin maddeler, humik ve fulvik asitler ile ayrıșma esnasında açığa çıkan diğer organik asitlerin, toprak pH'sının azalmasındaki farklılıklarda etkili olduğu düșünülmektedir.

Epstein (1976) , toprağa organik materyal

Çizelge 4. Organik materyallerin ve uygulama dozlarının $\mathrm{pH}$ üzerine etkisi.

Table 4. The effect of organic materials and application levels on $\mathrm{pH}$.

\begin{tabular}{cccc}
\hline \multirow{2}{*}{ Organik materyal } & \multicolumn{3}{c}{ Dozlar } \\
\cline { 2 - 4 } & $\% 1$ & $\% 2$ & $\% 4$ \\
\hline ÇG & $8.79 \mathrm{Aa}$ & $8.60 \mathrm{Aa}$ & $8.70 \mathrm{Aa}$ \\
BFA & $8.61 \mathrm{Aab}$ & $8.30 \mathrm{Bb}$ & $8.25 \mathrm{Bb}$ \\
TG & $8.46 \mathrm{Bb}$ & $8.39 \mathrm{Bb}$ & $8.69 \mathrm{Aa}$ \\
\hline
\end{tabular}

Aynı harfle gösterilen değerler arasındaki fark önemli değildir. Büyük harfler yatay, küçük harfler dikey karșilaștırma içindir. LSD0.05: 0,205 uygulamasının toprak pH'sında önemli bir değișmeye yol açmadığını belirtirken, pek çok araștırıcı organik materyal uygulamalarının toprak pH' sını azalttığını belirtmișlerdir (Șahin ve Kowald, 1989; Guidi ve Hall, 1983; Sing ve Kansal, 1985; Pikull ve Almanas, 1986). Diğer taraftan değișik SAR değerlerine (SAR=20 ve $S A R=40$ ) sahip sulama sularının toprakların $\mathrm{pH}$ değerleri üzerine etkilerini inceleyen Peker ve Öztürk (2020) toprakların tamponlama özelliğinden dolayı söz konusu sulama sularının toprak $\mathrm{pH}^{\prime}$ sında belirgin bir farklılık yaratmadığını bildirmișlerdir.

\section{Elektriksel İletkenlik (EC) Değerlerinin Değișimi}

Elektriksel iletkenliği bașlangıçta 3.9 dS/m olan toprağın, uygulamalar ve yıkama sonrasındaki elektrik iletkenlik değeri, en düșük 4.77 dS/m ile \%50 JG + \%4 ÇG uygulamasında, en yüksek ise $5.5 \mathrm{dS} / \mathrm{m}$ ile $\% 50 \mathrm{JG}+\% 2 \mathrm{TG}$ uygulamasında saptanmıștır (Çizelge 3). \%100 JG ve \%50 JG arasındaki fark istatistiksel olarak önemli bulunmamıștır. \%50 JG + \%4 ÇG uygulamasının diğer uygulamalara göre EC değerini azaltmada neden olduğu fark \% 100 JG'ne göre önemli, \% 50 JG göre önemsiz bulunmuștur. Kontrol toprakla karșılaștırıldığında jips ve organik materyal uygulamalarına bağlı olarak EC değerinde az da olsa yükselișler meydana gelmesinin sebebi ilave edilen jipsin neden olduğu tuzluluğun yıkama suyu ile yeterince uzaklaștırımamasından kaynaklandığı düșünülmektedir. Varyans analizinde organik materyaller ve dozların etkisi istatistiksel olarak önemli bulunmuștur $(P<0.05)$. Organik materyal $x$ doz interaksiyonu önemsiz bulunmuștur. Çizelge $5^{\prime}$ den gözüktüğü gibi, organik materyaller arasında 
çiftlik gübresi uygulamasında ortalama $4.92 \mathrm{dS} / \mathrm{m}$ ile en düșük, tavuk gübresi uygulamasında ise 5.41 dS/m ile en yüksek EC değerleri saptanmıștır. Dozlar dikkate alındığında ise en yüksek EC 5.29 dS/m ile $\% 1$ dozunda, en düșük ise 5,02 dS/m ile \%4 uygulamasında saptanmıștır. \%1 ile \%2 uygulama düzeyleri arasındaki fark önemsiz bulunmuștur. Organik materyallerin ortalaması dikkate alındığında ise en yüksek EC değeri 5,41 dS/m ile tavuk gübresi uygulamasında belirlenmiștir. Diğer organik materyallerle karșılaștırıldığında, bașlangıçta daha yüksek EC değerine sahip olan tavuk gübresinin bu özelliğinin uygulamalara da yansıdığı görülmüștür.

Çizelge 5. Organik materyallerin uygulama dozlarının EC $(\mathrm{dS} / \mathrm{m})$ üzerine etkisi.

Table 5. The effect of organic materials and application levels on $E C(d S / m)$.

\begin{tabular}{ccccc}
\hline \multirow{2}{*}{ Organikmateryal } & \multicolumn{3}{c}{ Dozlar } & \multirow{2}{*}{ Ortalama } \\
\cline { 2 - 4 } & $\% 1$ & $\% 2$ & $\% 4$ & \\
\hline CG & 5.03 & 4.97 & 4.77 & $4.92 \mathrm{C}$ \\
BFA & 5.40 & 5.17 & 5.0 & $5.19 \mathrm{~B}$ \\
TG & 5.43 & 5.50 & 5.30 & $5.41 \mathrm{~A}$ \\
Ortalama & $5.29 \mathrm{~A}$ & $5.21 \mathrm{~A}$ & $5.02 \mathrm{~B}$ &
\end{tabular}

Aynı harfle gösterilen değerler arasındaki fark önemli değildir. LSD 0.05: 0.112

\section{SAR Değerlerinin Değișimi}

Alkali toprağa jips ve organik materyal uygulamaları SAR değerlerini azaltmıștır. Deneme öncesi toprakta SAR değeri 61.0 iken, deneme sonrası uygulamalara bağlı olarak bu değer düșmüș ve SAR 25.28-36.46 değerleri arasında değișim göstermiștir (Çizelge 3). En düșük SAR değeri \%100 JG uygulamasında; en yüksek SAR değeri ise 36.46 ile \%50 JG + \%2 TG uygulamasında bulunmuștur. SAR değerindeki azalma, jips uygulamalarına bağlı olarak toprak solüsyonundaki çözünebilir kalsiyumun artmasına atfedilmiștir (Cass ve Sumner, 1982). Uygulamalara bağlı olarak ıslah parametrelerindeki değișimi gösteren Çizelge 3 incelendiğinde, \% 100 jips gereksinimi ile \% 50 jips gereksinimi arasındaki fark istatistiksel olarak önemli bulunmuștur $(p<0.05)$. \% 50 jips gereksinimleri ve organik materyal uygulamalarına ait SAR değerleri incelendiğinde ise, tavuk gübresinin $\% 2$ uygulama dozuyla $\% 50$ jips gereksinimi arasındaki farkın önemli $(p<$ 0.05), diğer organik materyal uygulamalarıyla olan ilișkisinin ise önemsiz olduğu saptanmıștır.
SAR değerlendirildiğinde organik materyaller ve dozların etkisi istatistiksel olarak $(p<0.05)$ önemli bulunmuștur. Buna karșın organik materyal $x$ doz interaksiyonu önemli değildir. Organik materyaller ve dozlar arasındaki karșılaștırmalarda ortalamalar arasındaki farklar önemlidir ( $p<0.05)$. Çizelge 6 'dan gözüktüğü gibi, uygulanan organik materyaller arasında çiftlik gübresi ortalama 32.33 SAR değeri ile en düșük değeri göstermiștir. Çiftlik gübresini, 33.57 ve 35.49 SAR değerleri ile sırasıyla BFA ve TG uygulamaları takip etmiștir. Uygulama düzeyleri dikkate alındığında ise en düșük SAR değeri 32.46 değeri ile \%4 uygulamasında bulunmuștur. \% 1 ve \%2 uygulama düzeyleri arasındaki fark önemsizdir.

Çizelge 6. Organik materyallerin uygulama dozlarının SAR üzerine etkisi.

Table 6. The effect of organic materials and application levels On SAR.

\begin{tabular}{ccccc}
\hline \multirow{2}{*}{ Organik materyal } & \multicolumn{5}{c}{ Dozlar } & \\
\cline { 2 - 4 } Ortalama & $\% 1$ & $\% 2$ & $\% 4$ & \\
\hline CG & 33.65 & 32.10 & 31.24 & $32.33 \mathrm{C}$ \\
BFA & 35.49 & 33.15 & 32.08 & $33.57 \mathrm{~B}$ \\
TG & 35.93 & 36.46 & 34.07 & $35.49 \mathrm{~A}$ \\
Ortalama & $35.02 \mathrm{~A}$ & $33.90 \mathrm{~A}$ & $32.46 \mathrm{~B}$ & \\
\hline
\end{tabular}

Aynı harfle gösterilen değerler arasındaki fark önemli değildir. LSD $0.05: 1.180$

\section{ESP Değerlerinin Değișimi}

Alkali toprağa farklı miktarlarda jips ve organik materyal uygulamaları ESP değerini düșürmüștür. Deneme öncesi ESP değeri 50.0 iken, deneme sonrası en düșük değer olarak \%100 JG uygulamasında 27.25 bulunmuștur (Çizelge 3). Çizelge 6 incelendiğinde, \%100 jips gereksinimi ve \%50 jips gereksinimi arasındaki fark önemli bulunmuștur $(p<0.05)$. Organik materyal uygulamaları incelendiğinde, TG, BFA ve ÇG uygulamalarının dozları arasındaki farkların önemsiz olduğu tespit edilmiștir. \%100 jips gereksiniminden sonra en düșük ESP 31.67 ile \% 50 JG + \%4 ÇG uygulamasında, en yüksek değer ise 35.05 ile \%50 JG + \%2 TG uygulamasında belirlenmiștir.

Ortalamalar dikkate alındığında, çiftlik gübresi uygulamasında 32.41 ile en düșük, tavuk gübresi uygulamasında ise 34.46 ile en yüksek ESP değerleri saptanmıștır (Çizelge 7). BFA ve ÇG uygulamaları arasındaki farklar önemsiz iken, her iki organik materyalin tavuk gübresi ile olan farkları önemli bulunmuștur ( $p<0.05)$. Uygulama düzeyleri dikkate alındığında ise \% 4 uygulama düzeyi $\% 1$ ve $\% 2$ uygulama düzeylerinden farklı bulunmuștur. 
Çizelge 7. Organik materyallerin ve uygulama dozlarının ESP üzerine etkisi.

Table 7. The effect of organic materials and application levels On ESP.

\begin{tabular}{|c|c|c|c|c|}
\hline \multirow{2}{*}{ Organik materyal } & \multicolumn{3}{|c|}{ Dozlar } & \multirow{2}{*}{ - Ortalama } \\
\hline & $\% 1$ & $\% 2$ & $\% 4$ & \\
\hline ÇG & 33.30 & 32.26 & 31.67 & $32.41 \mathrm{~B}$ \\
\hline BFA & 34.06 & 32.95 & 32.24 & $33.08 B$ \\
\hline TG & 34.78 & 35.05 & 33.56 & $34.46 \mathrm{~A}$ \\
\hline Ortalama & $34.04 \mathrm{~A}$ & $33.4 \mathrm{~A}$ & $32.49 \mathrm{~B}$ & \\
\hline
\end{tabular}

Aynı harfle gösterilen değerler arasındaki fark önemli değildir. LSD 0.05: 0.859

\section{SONUCLAR}

Jips ve organik materyal uygulamalarının ıslah parametreleri üzerindeki etkileri incelendiğinde, \%100 JG uygulaması ve \%50 JG uygulamalarının pH'yı düșürmedeki etkilerinin istatistiksel olarak önemsiz olduğu, organik materyal uygulamalarının etkilerinin dozla ilișkili olmayıp dalgalı bir değișim gösterdiği, bununla birlikte BFA uygulamalarının $\% 2$ ve \%4 dozlarının $\mathrm{pH}^{\prime} ı$ düșürmede diğer organik materyal uygulamalarından daha etkili olduğu tespit edilmiștir.

Uygulamaların EC üzerindeki etkisi toprak solüsyonunun EC'sini artırıcı yönde olmuștur. Tüm uygulamalarda EC kontrol toprağına göre yüksek bulunmuștur. $30 \mathrm{~cm}$ yıkama suyu düzeyinin, \% 100 JG ve \%50 JG uygulamalarından sonra toprak solüsyonunda artan tuz içeriğini uzaklaștırmada yeterli olmadığı görülmüștür. \%50 JG + organik materyal uygulama düzeylerinde, \%100 JG' de bulunan ESP ve SAR değerlerinden daha yüksek değerler saptanmıștır. Teorik olarak hesaplanan son ESP 15 değerine \%100 JG uygulamasında ulașılamamıștır. Bu durum özellikle bașlangıçta yüksek ESP içerikli ve araștırma toprağı gibi ağır killi topraklarda teorik olarak hesaplanan değerlerin üzerinde jips miktarlarının uygulanması gerektiğini ortaya koymuștur. Sonuç olarak \%100 JG 'nin alternatifi olabileceği düșünülen \%50 JG + organik materyal uygulamaları $\mathrm{pH}, \mathrm{EC}, \mathrm{ESP}$ ve SAR gibi temel ıslah göstergelerini iyileștirmede \% $100 \mathrm{JG}$ kadar etkili olamamıșlardır. Diğer taraftan çiftlik gübresi ESP ve SAR'ı düșürmede diğer organik materyallere nazaran kısmen daha etkili olmuștur. Organik materyallerin uygulama düzeyleri dikkate alındığında ise \% 4 dozu en etkin doz olarak saptanmıștır. \%100 JG ile birlikte organik materyal ilavelerinin daha fazla miktarda yıkama suyu ile uygulanmasının söz konusu alkali toprağın ıslahında etkinliği artırabileceği düșünülmektedir.

\section{KAYNAKLAR}

Abrol IP, Yadav, JSP, Massoud FI (1988). Salt-affected soils and their management. FAO 39, Rome, Italy.

Akalan,I, (1977).Toprak olușu,yapısı ve özellikleri. A.Ü.Zir. Fak.Yay.No: 662, Ankara

Bahtiyar M (1971). Erzincan ada çorak topraklarının olușu, özellikleri ve ıslahları üzerinde bir araștırma. Doktora Tezi. Atatürk Üniversitesi Ziraat Fakültesi, Erzurum.

Baran A, Çaycı G. Sözüdoğru Ok. (1998). The effect of beer factory sludge on some chemical and physical properties of a clay loam soil. In: Munsuz, N. (Ed.), Proceedings of M. Șefik Yeșilsoy International Symposium: Arid Region Soil. Menemen-izmir, Turkey, 21-24 September, 1998. pp. 179183.

Bose PC, Majunder SK, Datta RK (1992). Effect of amendments on chemical properties of alkali soil of mulberry garden and its yield. Indian Journal of Agriculture. 31 (2): 147150.

Bouyoucus, GL (1951). A recalibration of the hydrometer for making mechanical analysis of Soils. Agronomy J. 43:434438.

Bower CA, Reitmeir RF, Fireman M (1952). Exchangeable cation analysis of saline and alkali soils. Soil Science, 73: 251 261.

Cass A, Sumner ME (1982). Soil pore structural stability and irrigation water quality: I. Emprical sodium stability model. Soil.Sci. Soc. Am. J., 46 (3): 503-506.

DIN 1142 (1978). Torf für Gartenbau und Landwirstschaft.

EpsteinE, Taylor JM, Chaney RL (1976). Effects of sewage sludge and sludge compost applied to soil on some physical and chemical properties. Journal of Environment Quality, 5: $422-426$

Gabriels R, Verdonck O. (1992). Reference methods for analysis of compost. In: Merillot, D.V., Hermite, J.M. (Eds). Composting and quality assurance criteria. Commission of the European Communities, Luxembourg, p: 173-183.

Ghosh S, Lockwood SGP, Hulugalle N, Daniel H, Kristiansen P, Dodd K (2010). Changes in properties of sodic Australian vertisols with application of organic waste products. Soil Fertility \& Plant Nutrition, 74 (1):153-160.

Guidi G, Hall JE (1983). Effects of sewage sludge on the physical and chemical properties of soils. 3th International Symposium on processing and use of sewage sludge, Brighton, UK.

Hanay A, Büyüksönmez F, Kızıloğlu FM, Canbolat MY (2004). Reclamation of saline-sodic soils with gypsum and MSW compost. Compost Science and Utilization, 12(2); 175179.

Koç DL (2011). Așağı Seyhan Ovası tuzlu-sodyumlu toprakların farklı yöntemlerle iyileștirilmesi. Doktora Tezi. Çukurova Üniversitesi Fen Bilimleri Enstitüsü, Adana.

Kütük C, Çaycı G (2000). Effect of beer factory sludge on yield components of wheat and some soil properties. Proceedings of International Symposium on Desertification, 13-17 June 2000, Konya - Turkey, 324-328 
Munsuz N, Çaycı G, Sözüdoğru S (2001). Toprak ıslahı ve düzenleyiciler. Ank. Üni. Zir. Fak. Yay, Yayın No:1518, Ankara.

Nelson PN, Oades JM (1998). Organic matter, sodicity, and soil structure. (S. 76-91), (Eds: M.E. Sumner, R. Naidu) Sodic Soils. New York, Oxford University Press.

Peker AE, Öztürk H (2020). Sodyumlu sulama sularının toprak tuzluluk değișimine etkisi. Toprak Su Dergisi, 9 (2): 85 92.

Pikull JL, Almanas RR (1986). Physical and chemical properties of Haploxerall after fifty years of residue management. Soil. Sci. Soc. Am. J., 50(1): 214-219.

Puttaswamygowda J, Pratt PF (1973). Effect of straw, calcium chloride and submergence on a sodic soil. Soil. Sci. Soc. Am. Proc. 37.208-212.

Qadir M, Schubert S, Ghafoor A, Murtaza G (2001). Amelioration strategies for sodic soils: A review. Land Degradation \& Development, 12: 357-386.

Ranjbar F, Jalali M (2011). Effects of plant residues and calcite amendments on soil sodicity. Journal of Plant Nutrition and Soil Science, $174(6): 874-83$.

Sing J, Kansal BD (1985). Effects of long-term application of municipal waste water on some chemical properties of soils. Journal of Research Punjab Agr. Uni., 22: 235-242.

Șahin H, Kowald R (1989). Die moglichkeiten der abfall wermeidung verwortong und beseitung Inder Bun Derrepublik Deutschland.

Sönmez B, Beyazgül M (2008). Türkiye'de Tuzlu ve Sodyumlu Toprakların Islahı ve Yönetimi. Sulama ve Tuzlanma Konferansı 12-13 Haziran 2008, Șanlıurfa.
Tejada MC, Garcia C, Gonzales JL, Hernandez MT (2006). Use of organic amendments as a strategy for saline soil remediation: Influence on the physical, chemical and biological properties of soil. Soil Biol. Biochem. 38 : 14131421 .

Temiz C., Akca MO, Çayci G, Baran A (2021). Assessment of the effect of different compost materials on aggregation and mechanical properties in an Entisol. Communications in Soil Science and Plant analysis, Doi: 10.1080/00103624.2020.1869770.

Tozsin G, Arol Al, Cayci G (2014). Evaluation of pyritic tailings from a copper concentration plant for calcareous sodic soil reclamation. Physicochemical Problems of Mineral Processing, 50 (2): 693-704.

U.S. Salinity Lab. Staff (1954). Diagnosis and improvement of saline and alkali soils. Agric. Handbook No: 60. P 160. Washington. D.C.

Ülgen N, Ateșalp M (1972). Topraklarda organik madde tayini. Toprak Gübre Araștırma Enstitüsü. Teknik Yayınlar serisi no:23. Ankara.

Yakupoğlu T, Özdemir N (2007). Tuzluluk ve alkaliliğin toprağın bazı fiziksel özellikleri üzerine etkileri. O.M.Ü. Ziraat Fakültesi Dergisi, 22(1):132-138.

Yurtseven E (2000). Patlıcanda (Solunum Melongena L.) su tüketimine tuzluluğun etkisi. Toprak Su Dergisi, Sayı: 2, Ankara. 